effect to the suggestion of the use of frog skin for grafting purposes. My first use of it was in my own case. I had suffered for nearly three years from obstinate ulceration of the skin of the foot which had resisted all treatment and steadily refused to heal. When I mention that I consulted several eminent surgeons, among them the late Sir James Paget and the late Sir William Savory, it will be recognised that $I$ had the best advice obtainable. To make a long story short, I commenced using grafts of frog skin in the middle of January, 1885, and in less than six weeks had a sound covering of skin. At the present time, more than 20 years having elapsed, the cicatrix is perfectly sound, and has none of the puckering and stiffness so often seen in cicatrices where human grafts have been used. In fact, it is impossible without very close examination to see the cicatrix at all, and yet the ulcerated surface extended over the dorsum of the foot round under both malleoli and there was only a bridge of skin about two inches in width left at the back of the foot. I was so encouraged by this result that $I$ used frog skin in every case of the kind after that, and at a rough estimate must have used it in some 300 or 400 cases, in all with good results at the time and I doubt not with equally permanent effects, though naturally I have not been able to keep in touch with the patients. I published a note on the subject in 1886 or $188^{\prime} 7$ and the procedure was specially brought under the notice of the medical services in India by the then surgeon-general, but, I fear, with little result.

My object in writing this letter is to elicit information as to the recognition by the profession of the value of this metbod of grafting with frog skin. It is so simple and easy and so entirely unobjectionable that I cannot but feel that it shou'd in all cases replace the use of human skin.

Oxford, Oct. 26th, 1906

$$
\text { I am, Sirs, yours faithfully, }
$$

GEORGE RANKING.

\section{THE DISPOSAL OF REFUSE WHEN GAS IS USED FOR COOKING. \\ To the Editors of THE LANCET.}

SIRS,-Will you permit me space to say, in reference to your recent remarks on the possible danger to health arising from animal and regetable refuse not being immediately destroyed in the many houses where gas is exclusively emplojed for cooking, that, where no such facilities exist for the prompt removal of refuse as are to be found in con. nexion with most blocks of flats in London, there are more ways than one of dealing with the problem.

In the first place, it is already the practice in some house. holds to do as Mrs. Marshall suggests-namely, to light the "copper" fire daily for the dual purpose of burning refuse and of heating water for "washing-up" and other purposes. This plan, however, is not so completely satisfactory as is the second to be mentioned, which is indeed that which may be strongly recommended on all grounds. This second plan is to instal in the kitchen, together with the gas cooker, a coke-fired boiler connected with the hot-water circulating system. The gas stove can then $b$; always used for cooking, while the coke-fired boiler not only provides the constant hot-water supply, but can also be utilised as a refuse crematorium and will give sufficient warmth and cheerfulness to the kitchen in winter if the fire door is left open, while the kitchen will remain cool in summer if the boiler and the pipes leading from it are well insulated and the fire door is kept closed. 'This plin has been advocated on several occasions by Dr. H. A. Des Veux (the treasurer of the Coal Smoke Abatement Suciety) on the strength of his own experience, but has not perhaps been brought with suffi cient prominence before the general public. So far as this company is concerned, I may say that we are taking steps to bring the system to the notice of all our consumers (the great majority of whom are users of gas for cooking) as it is undoubtedly a most excellent one from every point of viewwhether from that of health, convenience, comfort, or economy.

The following quotation from a paper read by Dr. Des Voux at the Conference of Smoke Abatement last December may be of interest to your readers :-

I believe that it is not you sanitarians who are going to lead the way, but a person much more useful and practical in serving the needs of mankind-I mean our friend who presides in the kit chen, our cook. It is she who has found out that a gas kitchener is essential in a house, and it is she who has discovered its advantages while you have been looking on! But, unfortunately, smoke is still emitted from the kitchen chimney, for in all moderately large houses it is necessary to
have a hot-water system as well, and in most houses the old coal range is lighted for this purpose. IIow, then, can the hot water be supplied? Wight yoars ago I installed a coke boiler and each year I am more satisfied with it. It has given a magnificent hot-water supply throughout the house at a temperature of about $170^{\circ} \mathrm{F}$, and the supply has been so plentiful that I have been enabled to put three hot-water rasiators into passages. The cost of this system is from 1s. $3 d$. to $2 s$. a week, depending mostily on the price of coke. With a gas cooker and a coke boiler, the difficulties of a hot-water system and the warmth of the kitchen are surmounted. If this system were installed in all the houses in London, the greater part of the smoke from private houses would be prevented.

A third method of dealing with the refuse problem is that of having a special refuse-destructor, heated by gas, in which all rubbish can be speedily destroyed with a small consumption of fuel. We have recently fixed several of these for use in large boarding houses and they would certainly be extremely useful for restaurants, hotels, and large establishments generally, if not for the average household-for which the water-heating, kitchen-warming and refuse-destroying cokeheated boiler is in every way suited.

The pity of it is that the architects and builders have not yet, for the most part, realised that such a thing as a gas cooker exists, although there are few households nowadays in which one is not to be found. When our friends do awake to the fact that gas is rapidly becoming the staple fuel of the ILondon householder, perhaps they will make proper provision for its use in the kitchens as well as in the other rooms of the houses and fl $\mathrm{tts}$ they design and construct. I hope that the importance of the subject may be sufficient excuse for this somewhat lengthy communication.

I am, Sirs, yours faithfully,

D. Milie Watson, General Manager.

The Gas Light and Coke Company. Horseferry-road, Westminster, S.W., Oct. 31st, 1906.

\section{To the Editors of THE LANCET.}

SiRs, - I have just read an extract from THE LaNChT in an evening paper stating that the inability of the gas stove to burn off vegetable and other refuse, with the consequent lack of ashes in the dust-bin, is likely to prove a serious menace to the family hygiene. May I suggest that the ordinary boiler or "copper" (generally unused in the majority of houses) forms a most economical and effective crematorium and gives a splendid supply of hot water at a minimum cost. A few sticks and two shovelfuls of coal will soon bring a copper holding 14 or 16 gallons to the boiling point, after which, cinders, pea-shells, potato-peelings, cabbage-stalks, faded flowers, and all the heterogeneous mass of household refuse can be reduced by slow combustion to ashes. If householders and housekeepers would insist on this being done as part of the day's routine they would find their gas bill very much reduced, for the heating of water runs up the gas consumption terribly. Once brought to near the boiling point the water in the copper will remain hot enough for washing dishes, scrubbing, \&c., for eight or ten hours, without the addition of any more fuel than house refuse. The convenience of a constant supply of hot water should commend itself to both mistress, cook, or artisan's wife, while the dustbin is worthy of its name, and holds nothing but ashes and needs to be emptied only when full, instead of every day.

Gas-cookers are not an unmixed good. I believe the penny-in-the-slot stove has aimost as much to do with the appalling infant mortality among the poorer class as the compulsory sending of all the helpful children to school. Clothes are not aired; the room is not ventilated by a fire; there is no inducement for the mother to sit down and let the baby stretch its little iimbs in the warmth; but the "labour-saving" stove is a godsend to the boneless, boardschool educated wife, whose maternal faculty (thanks to our legislation) atrophies before it is fully developed. When will the authorities learn the national importance of encouraging maternity; even at the expense of girls with less "education," and more time among the babies and in the home?

Nov. 3rd, 1906. Ellis Peyton.

\section{PURIN-FREE DIETS.}

\section{To the Editors of $\mathrm{TH} \mathbf{\mathrm { E }} \mathrm{LANCET}$.}

SIRs, - In common with many others I read with great appreciation Dr. Harry Camphell's series of pajers on the Evolution of Man's Diet appearing in THE LANCET last year. In view of his conclusion that man has reached his present position in the scale of evolution on "a highly animalised diet," his suggestion at the end of his letter in your issue of Oct. 27 th is of extreme interest. It might seem 